\title{
Sustainability Assessment of Sanitation Indicators in the PCJ Watersheds 2020- 2035 Plan
}

\author{
João Miguel Merces Bega \\ André do Vale Borges \\ César Ambrogi Ferreira do Lago \\ Jakeline Pertile Mendes \\ Paulo de Tarso de Azevedo \\ Welington José Rocha dos Santos \\ Duarcides Ferreira Mariosa
}

- Escola de Engenharia de São Carlos (Universidade de São Paulo), São Carlos, São Paulo, Brazil.

(D) Escola de Engenharia de São Carlos (Universidade de São Paulo), São Carlos, São Paulo, Brazil.

(D) III Escola de Engenharia de São Carlos (Universidade de São Paulo), São Carlos, São Paulo, Brazil.

(D) Iv Pontifícia Universidade Católica, Campinas, São Paulo, Brazil.

D Vaculdade de Saúde Pública (Universidade de São Paulo), São Paulo, São Paulo, Brazil.

D ${ }^{V I}$ Escola de Engenharia de São Carlos (Universidade de São Paulo), São Carlos, São Paulo, Brazil..

VII Pontifícia Universidade Católica, Campinas, São Paulo, Brazil.
Abstract: Understanding how variables that integrate sustainability indexes behave is essential due to the limitation of natural resources under a growing demand. Based on case study and exploratory research techniques, this paper aimed to analyze the levels of collected and treated wastewater in the PCJ Basins Water Resources Plan for the 2020-35 period. We sought to validate the indicators based on Gibson's sustainability principles, relating them to the 6.2 and 6.3 targets of the Sustainable Development Goal (SDG) 6. It was concluded that the indicators are important to evaluate processes to achieve SDG 6. However, the indicators have flaws and can mask important information, preventing more assertive decision making. The target to achieve the 2035 reference scenario was found to be valid for four of Gibson's sustainability principles.

Keywords: Sustainability indicators; SDG 6; Gibson's sustainability principals; sustainable basins.

São Paulo. Vol. 24, 2021

Special Issue:

Sustentare and International Workshop on Sustainability Indicators (WIPIS)

DOI: http://dx.doi.org/10.1590/1809-4422asoc20190031r3vu2021L3AO 


\section{Introduction}

There is a lack of consensus in the scientific world regarding the interpretation of the term 'sustainable development' given that the various authors base themselves on different paradigms and the term is also frequently confused with sustainability itself (SARTORI; LATRÔNICO; CAMPOS, 2014). The word development suggests the idea of gradual, directed change and does not necessarily imply quantitative growth; it is more like a qualitative ramification of increasingly complex potentialities which, depending on the case, may or may not involve quantitative growth (GALLOPÍN, 2003). Dovers and Handmer (1992) defined sustainability as "the ability of a human system, natural or mixed, to resist or adapt to endogenous or exogenous change indefinitely, and, in addition, Sustainable Development is a way of intentional change and improvement that keeps or increases this attribute of the system meeting the needs of the population." Feil and Schreiber (2017) have proposed that sustainability is the reflection of the relations between the human being and the environment, and that sustainable development is a learning process directed by public policies orientated by a national development plan. The Brundtland report (WCED, 1987) presented sustainable development in a simpler way, as being the development that satisfies the needs of the present without jeopardizing the capacity of future generations to satisfy their own necessities. That definition allows for interpretations which makes it a lasting one (GIOVANNONI; FABIETTI, 2014; SARTORI; LATRÔNICO; CAMPOS, 2014).

Sustainability assessment is a recent environmental impact evaluation structure that emphasizes the delivery of net positive sustainability gains now and in the future (BOND et al., 2012). Hacking and Guthrie (2008) have defined it as any process that guides decision makers towards sustainability. There is, as yet, no universal agreement as to what the assessment of sustainability really is or how it should be applied. Gibson (2012) has reported that best practice must take into consideration a system rather than the alignments of the social, environmental and economic pillars. International practice varies, depending on legal actions, governance structures and the concept of sustainability that is incorporated to the respective process (ESTEVES et al., 2012).

One way of quantitatively assessing sustainability is by using indexes and indicators. Sustainability indicators are tools used to assist in monitoring the operationalization of sustainable development. An indicator is developed with the intention of getting to know a given reality and must be capable of synthesizing a whole set of complex information and of exposing the essential meaning of the analyzed aspects (SINGH et al., 2012).

Flint (2004) addressed sustainable development in river basins as being a multidimensional way of thinking about the connections and interdependencies among natural, social and economic systems in the use of water in such a way that the endeavors to achieve economic vitality would be made in the context of improving and preserving ecological integrity, social wellbeing and security for all. In 2018, the Piracicaba, Capivari and Jundiaí River Basins Agency (Agência das Bacias dos Rios Piracicaba, Capivarie Jundiaí - PCJ) became the first basin board in the world to sign the term of adhesion to the United Nations (UN) Global Pact (AGÊNCIA DAS BACIAS PCJ, 2020). The initiative seeks 
to mobilize the international community towards the adoption of accepted fundamental values in various areas (e.g., human rights, and environment) which would endow the actions related to the Sustainable Development Goals (SDGs) of the agency itself with greater efficiency and visibility. Since 1994, State of the Basin reports have been elaborated for the PCJ basins and from 2007 on they have followed the methodology recommended by the Infrastructure and Environment Department (Secretaria de Infraestrutura e Meio Ambiente - SIMA) which foresee the use of a set of indicators organized in a hierarchical structure known as the 'matriz FPEIR' (Força-Motriz, Pressão, Estado, Impacto e Resposta [Driving force, Pressure, State, Impact and Response]).

The PCJ basins guarantee the water supply of 5.8 million people in their areas and another nine million in the Metropolitan Region of São Paulo (MRSP) (AGÊNCIA DAS BACIAS PCJ, 2020). In 2018, the water offer in the basins was approximately 971 $\mathrm{m}^{3}$.inhab ${ }^{-1}$.year ${ }^{-1}$, an unsatisfactory amount according to the reference standards adopted by the State of São Paulo which is $<1.500 \mathrm{~m}^{3}$. inhab $^{-1}$.year ${ }^{-1}$ (SÃO PAULO, 2020). In terms of water resource criticality (COMITÊ DAS BACIAS PCJ, 2018), the least sustainable sub-basins are those of the Piracicaba and Capivari rivers because they have the greatest volumes of water capture and concentrate a considerable part of the population so that the demand-availability situation is critical. $60 \%$ and $38 \%$ of the municipalities have good classification in regard to wastewater collection and wastewater treatment, respectively (AGÊNCIA DAS BACIAS PCJ, 2020). The data reveal the need to evaluate the percentage of treated wastewater as a percentage of the total volume of wastewater generated because analyzing it in relation to the amount collected alone masks the information as to how much was not collected.

Sustainable development cannot be restricted to economic development alone; it must embrace a wider range of concepts including those associated to the quality of life. It is therefore admissible to include water use and the generation of sanitary effluents in the SDGs (PNUD-BR, 2020). SDG 6 establishes eight targets monitored by eleven indicators and it addresses the questions of drinking water and sanitation (BRASIL, 2019a). Therefore, the present work sets out to evaluate the indicators 'collected wastewater' and 'treated wastewater' of the Water Resources Plan (WRP) of the PCJ basins (Plano de Recursos Hídricos-PRH-das Bacias PCJ) (AGÊNCIA DAS BACIAS PCJ, 2020), and relate them to targets 2 and 3 of SDG 6 . To gain an understanding of future scenarios the study analyzed the estimates for the years 2025, 2030 and 2035 (COMITÊ DAS BACIAS PCJ, 2020) checking their validity in the light of the principles Gibson (GIBSON, 2006b) proposed. The investigation is based on a case study and all the information has been obtained from secondary sources.

The value of this study is that it underscores the increasing importance of the activities of the PCJ Basins Agency and seeks to contribute towards enhancing economic, social and environmental aspects of its sustainability management in the sense of reducing the risk of an eventual water crisis that would affect economic and social development not only in the region of the basins but also in entire MRSP. 


\section{Theoretical Reference Framework}

\subsection{Sustainable Development Goals}

In September 2015, world leaders gathered at UN headquarters in New York to define an Action Plan to eradicate poverty, protect the planet, and ensure that all people enjoy peace and prosperity. What emerged was the 2030 Agenda for Sustainable Development (AGENDA, 2030).

The SDG, also known as the Global Goals, are universal actions structured around 17 goals and established in the molds of the Millennium Development Goals (MDGs). The latter consisted of eight global goals that the UN member nations set for themselves in order to achieve rapid progress worldwide directed at eliminating extreme poverty and hunger from the planet (ROMA, 2019). The SDGs incorporated important new goals to address the contemporary reality such as those directed at economic inequality, climate change, innovation and sustainable consumption (PNUD-BR, 2020). The UN conducts global monitoring of the goals by means of the annual meeting of the High-Level Political Forum on Sustainable Development at which the countries present their annual progress reports and comparisons are made among them (SILVA, 2018).

Given the cross-cutting nature of water and the (economic, social and environmental) harm that stems from uncollected and untreated wastewater, SDG 6 is to "Ensure availability and sustainable management of water and sanitation for all." On the global scale, the Inter Agency Expert Group on SDG indicators has developed a set of indicators which are used to monitor and review the SDG goals and targets (SILVA, 2018). The UN Statistical Commission has analyzed and verified those indicators, selected according to the target to be achieved and Chart 1 below displays the SDG 6 targets and the corresponding indictors.

Although the SDG 6 indicators are analyzed country by country, the statistics calculated at the levels of States, Geographic regions and Hydrographic regions can be very useful for the management of more critical areas. Furthermore, recognizing the obstacles countries face, the UN can recommend viable alternatives to calculations of the SDG 6 indicators to encourage those countries that have not taken any measures towards achieving the goal (BRASIL, 2019a).

\subsection{Water Sustainability Indicators in the PCJ Basins}

Water security is a broad term that refers to the guaranteed availability of water for its various uses. It involves populations' capacity to "safeguard sustainable access to adequate quantities of acceptable quality water for sustaining livelihoods, human wellbeing, and socio-economic development, for ensuring protection against water-borne pollution and water-related disasters, and for preserving ecosystems..." (UNITED NATIONS WATER, 2013). Thus, basic sanitation is of fundamental importance for achieving water security. 
Information surveys of the PCJ Basins (COMITÊ DAS BACIAS PCJ, 2018) have made it possible to assess the sanitation conditions in the region based on indicators associated to wastewater collection and treatment and water distribution and consumption. The domestic supply indicators show that in 2017, 98\% of the urban population and $94 \%$ of the rural population in the basins received potable water. An analysis of the classification of the indexes based on the criteria adopted by the coordinating body for water resources in the State of São Paulo (Coordenadoria de Recursos Hídricos do Estado de São Paulo) (SÃO PAULO, 2020), considering the urban area alone, shows that $80 \%$ of the municipalities received a classification of 'good'. On the other hand, when the rural figures are included the classification percentage drops to $23 \%$. By developing plans to cut losses from the system, classified as 'regular' for almost half of the municipalities, it would be possible to cut costs in water treatment and distribution. Apart from that, improvements for the rural populations need to be considered.

The study also evaluated water demand sustainability considering water criticality calculated on the basis of the water balance for the region for the year 2016 and obtained by subtracting the water demands from the water availability and then adding the transpositions and returns. According to the PCJ Basins Committee (2018), criticality is high when the balance is negative. A balance below $50 \%$ of the $Q_{7,10}$ (a statistical estimate of the lowest average flow for seven-day period with an average recurrence interval of ten years) corresponds to high criticality; between $50 \%$ of the $Q_{7,10}$ and at $Q_{95}$ (the flow value which the river exceeds more than $95 \%$ of the time) corresponds to a medium criticality; and low criticality occurs when the balance is greater than $Q_{95}$. The Capivari river sub-basin showed the highest percentage of the areas of contribution (40\%) with high and very high criticalities. The most unsustainable situations were those of the subbasins of the Capivari and Piracicaba rivers, with relations demand/availability of $173 \%$ and $144 \%$, respectively.

Water availability is directly related to the quality of the surface waters. The WRP for the PCJ basins has eight indicators associated to it among which are the Water Quality Index (Índice de Qualidade das Águas - IQA) and the Untreated Water Quality Index (Índice de Qualidade da Água Bruta para Abastecimento Público - IAP). The analysis of those indicators shows that the poorest quality water for public supply is in the sub-basins of the Capivari and Piracicaba rivers. That means it is of fundamental importance to ensure the good quality of rivers in the PCJ basins in order to achieve sustainability and promote water security. Improvement and expansion of the water collecting network and the wastewater treatment services can contribute to improving water quality.

The Plan also addressed the possibility of inventorying points of pollution by means of wastewater collection and treatment indicators; such identification could help to formulate a plan for improving water quality by investing in sanitation. 
Chart 1 -SDG 6 targets and their respective indicators.

\begin{tabular}{|c|c|c|}
\hline Target & Description & Indicators \\
\hline 6.1 & $\begin{array}{l}\text { By 2030, achieve universal and equitable } \\
\text { access to safe and affordable drinking } \\
\text { water for all; }\end{array}$ & $\begin{array}{l}\text { 6.1.1 -Proportion of population } \\
\text { using safely managed drinking } \\
\text { water services; }\end{array}$ \\
\hline 6.2 & $\begin{array}{l}\text { By 2030, achieve access to adequate and } \\
\text { equitable sanitation and hygiene all and } \\
\text { end open defecation paying special atten- } \\
\text { tion to the needs of women and girls and } \\
\text { those in vulnerable situations; }\end{array}$ & $\begin{array}{l}\text { 6.2.1 -Proportion of population } \\
\text { using (a) safely managed services } \\
\text { and (b) a hand-washing facility } \\
\text { with soap and water; }\end{array}$ \\
\hline 6.3 & $\begin{array}{l}\text { By } 2030 \text {, improve water quality by redu- } \\
\text { cing pollution, eliminating dumping and } \\
\text { minimizing release of hazardous chemi- } \\
\text { cals and materials, halving the proportion } \\
\text { of untreated wastewater and substantially } \\
\text { increasing recycling and safe reuse glo- } \\
\text { bally; }\end{array}$ & $\begin{array}{l}\text { 6.3.1 -Proportion of domestic and } \\
\text { industrial wastewater flows safely } \\
\text { treated; } \\
6.3 .2 \text {-Proportion of bodies of } \\
\text { water with good ambient water } \\
\text { quality; }\end{array}$ \\
\hline 6.4 & $\begin{array}{l}\text { By 2030, substantially increase water-use } \\
\text { efficiency across all sectors and ensure } \\
\text { sustainable withdrawals and supply of } \\
\text { freshwater to address water scarcity and } \\
\text { substantially reduce the number of people } \\
\text { suffering from water scarcity; }\end{array}$ & $\begin{array}{l}\text { 6.4.1 -Change in water-use effi- } \\
\text { ciency over time } \\
\text { 6.4.2 - Level of water stress: } \\
\text { freshwater withdrawal as a pro- } \\
\text { portion of available freshwater } \\
\text { resources; }\end{array}$ \\
\hline 6.5 & $\begin{array}{l}\text { By } 2030 \text {, implement integrated water } \\
\text { resources management at all levels, inclu- } \\
\text { ding through transboundary } \\
\text { cooperation as appropriate; }\end{array}$ & $\begin{array}{l}\text { 6.5.1 -Degree of integrated water } \\
\text { resources management; } \\
6.5 .2 \text {-Proportion of transboundary } \\
\text { basin area with an operational ar- } \\
\text { rangement for water cooperation; }\end{array}$ \\
\hline 6.6 & $\begin{array}{l}\text { By 2020, protect and restore water- rela- } \\
\text { ted ecosystem, including mountains fo- } \\
\text { rests, wetlands, rivers, aquifers and lakes; }\end{array}$ & $\begin{array}{l}\text { 6.6.1 - Change in the extent of } \\
\text { water-related ecosystems over } \\
\text { time; }\end{array}$ \\
\hline $6 . \mathrm{a}$ & $\begin{array}{l}\text { By 2030, expand international coope- } \\
\text { ration and capacity-building support } \\
\text { to developing countries in water- and } \\
\text { sanitation-related activities and progra- } \\
\text { ms, including water harvesting, desalina- } \\
\text { tion, water efficiency, wastewater treat- } \\
\text { ment, recycling and reuse technologies; }\end{array}$ & $\begin{array}{l}\text { 6.a.1-Amount of water-and } \\
\text { sanitation-related official develo- } \\
\text { pment assistance that is part of a } \\
\text { government-coordinated spending } \\
\text { plan; }\end{array}$ \\
\hline
\end{tabular}




\begin{tabular}{|l|l|l|}
\hline $6 . b$ & $\begin{array}{l}\text { Support and strengthen the participation } \\
\text { of local communities in improving water } \\
\text { and sanitation management. }\end{array}$ & $\begin{array}{l}\text { 6.b.1 -Proportion of local adminis- } \\
\text { trative units with established and } \\
\text { operational policies and procedures } \\
\text { for participation of local communi- } \\
\text { ties in water and sanitation mana- } \\
\text { gement. }\end{array}$ \\
\hline
\end{tabular}

Source: Elaborated by the authors with Silva data (2018).

\subsection{Gibson's principles.}

The principles describe a set of fundamental laws or rules used to govern the behavior of a system (FLINT, 2013). Determining which aspects of a system need to be monitored and which variables could evaluate the state and performance of those aspects is the principal challenge involved in sustainability endeavors (WU; WU, 2012). Flint (2013) has explained that even though sustainability principles are varied and usually have specific political contexts nevertheless, they address a common set of implicit issues such as ecological integrity, social equality and the sustainability tripod (social, environmental and social aspects).

The principles are based on the perception that human and environmental wellbeing are interdependent and that, inevitably, the human being depends on biospheric conditions and plays a fundamental role in manipulating them (GIBSON, 2006a). That being so, sustainability principles expand the concept of ecosystems to become one of dynamic, durable, adaptable and resilient socioenvironmental systems.

The search for more cross-cutting models in regard to the sustainability triple base line or tripod was designed to introduce a multi-factor and interdisciplinary approach so as to advance understanding of the integrity of the social, economic and environmental dimensions and minimize the customary trade offs on issues of fairness and biodiversity conservation (HACKING; GUTHRIE, 2008). Gibson et al. (2005) captured and synthesized the basic principles of sustainability that are frequently used by Agencies and scholars when assessing sustainability in an integrated manner, represented by developing projects, specific assessment guidelines and strategic-level structures. Gibson (2006b) presented an integrating decision-making model, respecting the interconnections among objectives, actions and effects with a view to monitoring the results.

In synthesis, the model is based on eight fundamental principles; their order of presentation does not signify their order of importance relative to one another: 1) Longterm integrity of the environmental system: seeks to protect the irreplaceable life-support systems; 2) resources sufficient for a decent life and access to subsistence opportunities that do not jeopardize future generations; 3) Intragenerational equity: seeks to reduce the lacks of opportunity among the different socioeconomic classes; 4) Intergenerational equity: favors actions of preservation or improvement of opportunities for future generations to live sustainably; 5) Resource maintenance and efficiency: reduces the long-term threats to the integrity of the socioenvironmental systems; 6) Socioenvironmental civility 
and democratic governance for the construction of collective decisions among individuals, communities and various other entities; 7) Precaution and adaptation: respect uncertainty, avoiding risks of serious or irreversible harm to the fundaments of sustainability, even if they are barely understood; and 8) Immediate and long-term integration: applies all the sustainability principles at the same time endeavoring to obtain mutual benefits and multiple gains on the path to sustainability.

\section{Methodological Procedures}

\subsection{Characterization of the PCJ basins}

The headquarters of the PCJ Basins Agency (Agência das Bacias PCJ) is in the city of Piracicaba in the interior of the state of São Paulo (BRASIL, 2019b). The PCJ basins occupy a territorial space of $15,377 \mathrm{~km}^{2}$ located between longitudes $45^{\circ} 50^{\prime}$ and $48^{\circ} 30^{\prime}$ west and latitudes $22^{\circ} 00^{\prime}$ and $23^{\circ} 20^{\prime}$ south with $92.45 \%$ in the state of São Paulo (71 municipalities) and $7.55 \%$ in the state of Minas Gerais (5 municipalities). Three basins are located in that drainage area: that of the Capivari River $\left(1,568 \mathrm{~km}^{2}\right)$, the Jundiaí River $(1,154$ $\mathrm{km}^{2}$ ) and the Piracicaba River (12,655 km²) (AGÊNCIA DAS BACIAS PCJ, 2020).

In hydrological terms, the region is divided into seven sub-basins, five belonging to the Piracicaba river (Piracicaba, Corumbataí, Jaguari, Camanducaia and Atibaia) plus the sub-basins of the Jundiaí and Capivari. Among the main rivers in the region the Jaguari, Piracicaba, Atibaia and Camanducaia rivers are in the federal domain while the Corumbataí, Capivari and Jundiaí come under state authority. In regard to land use in the basins there is a predominance of open country $(25.30 \%)$, native vegetation $(20.35 \%)$, farmland (19.02\%) and urbanized areas (12.11\%) (EMPLASA, 2015).

For the year 2020, the estimated population of the basins was 5.8 million (AGÊNCIA DAS BACIAS PCJ, 2020). According to IBGE data the conditions of the households are good. In the urban areas more than $99 \%$ have electricity supply, more than $94 \%$ have piped water supply and $88 \%$ are connected to the general wastewater network. In the case of the rural households, $99 \%$ have access to electricity, the predominant forms of water supply are wells or springs on the property and most of the effluents generated go to septic tanks or rudimentary latrines.

In 2014, the municipalities of the PCJ basins represented 17\% of Brazil's Gross Domestic Product (GDP) with the main participations being: Campinas (18.3\%), Jundiaí $(11.5 \%)$ and Piracicaba (7\%) (AGÊNCIA DAS BACIAS PCJ, 2020). In comparisons of the Municipal Human Development Indexes (MHDI) of the cities located in the PCJ basins with those of the state of São Paulo as a whole (Average HDI: 0.783) it can be seen that $67.1 \%$ registered growth in the index equal to or greater than the state average.

\subsection{Method}

The present research is a case study, exploratory insofar as it seeks to increment the understanding of the problem in analysis and help towards the development of aspects of 
importance for the objective intended to be achieved (MATTAR, 2000). The procedure adopted was to gather information from secondary sources in the form of scientific articles and reports made available by governmental organizations and public service concession holders. In that way the risk of conducting an inefficient and/or meaningless study was avoided, economizing efforts and resources. In regard to the documental aspect, the information considered was that of the PCJ Basins Agency itself (e.g., COMITE DAS BACIAS PCJ, 2018; AGÊNCIA DAS BACIAS PCJ, 2020).

Two of the WRP monitoring indicators for the PCJ basins were studied (collected wastewater and treated wastewater) endeavoring to relate them to the achievement of targets established by the SDG 6 (BRASIL, 2019a), specifically 6.2 and 6.3. To evaluate future scenarios associated to those indicators the study examined the estimates for the years 2025, 2030 and 2035 (COMITÊ DAS BACIAS PCJ, 2020) and also verified their validity in the light of the principles proposed by Gibson (GIBSON, 2006b) to obtain an idea of PCJ basins' sustainability for a horizon of 2035.

\section{Results and Discussion}

4.1 Panorama of Wastewater in the the PCJ Basins in relation to SDG 6

Under this heading the current situation of the PCJ basins regarding the collected wastewater and treated wastewater indicators is addressed together with other sanitation-related indicators, such as the Wastewater Collection and Treatability Indicator (Indicador de Coleta e Tratabilidade de Esgoto - ICTEM) and the Untreated Water Quality Index (IAP). The PCJ Basins Plan 2020-2035 (COMITÊ DAS BACIAS PCJ, 2020) is designed to achieve improvements to the current deficiencies in future scenarios (2025, 2030 and 2035).

Among analyses of other sanitation aspects, the State of the PCJ Basins Water Report (Relatório de Situação dos Recursos Hídricos das Bacias PCJ) (COMITÊ DAS BACIAS PCJ, 2019) offers an analysis of the water supply and wastewater situation in the municipalities of Water Management Unit 5 (Unidade de Gerenciamento de Recursos Hídricos - UGRHI - 05) of the State of São Paulo. Every year the Environmental Company of the State of São Paulo (Companhia Ambiental do Estado de São Paulo - Cetesb) gathers data on wastewater from the São Paulo municipalities and by means of its ICTEM evaluates the system's efficacy. The ten most populated cities in the PCJ basins (Campinas, Piracicaba, Jundiaí, Limeira, Sumaré, Americana, Santa Bárbara D’Oeste, Rio Claro, Hortolândia and Indaiatuba) are those that present the best results, showing that actions are indeed being carried out to achieve water sustainability. The gains go beyond the environmental plan insofar as they consider the MHDI. According to United Nations Development Program data for the year 2010 four out of ten of the abovementioned municipalities presented very high MHDI indexes (MHDI $>0.800)$ and the remaining six, high indexes (from 0.700 to 0.799 ).

On the other hand, according to the Situation Report for 2018 (COMITÊ DAS BACIAS PCJ, 2019), 9 of the 27 municipalities that lie within the UGRHI presented 
ICTEM values (on a scale from 0.0-10.0) ranging from 0.0 to 2.5. The report shows that the worst wastewater situations are in the cities located in the headwaters areas with potential negative impacts on public water supply systems downstream.

To enhance the understanding of the impacts of those regions with the lowest ICTEM values on the surface waters of the basins, this study also evaluated the IAP. Actually, only one municipality, Monte Alegre do Sul, had a satisfactory indicator value and all the others were deficient in regard to the quality of water for public supply varying from fair to very bad.

The low IAP values in the municipalities with the lowest ICTEM values becomes even more visible when an analysis is made of the availability of surface waters and underground waters in PCJ basins. Since 2016, drops of around $10 \mathrm{~m}^{3}$.inhab ${ }^{-1}$ have been registered in the general context of surface water availability (Figure 1). Added to that, there is an increasing demand for subterranean waters. 
Figure 1 - Annual records of per capita water availability and the demand for water in the PCJ basins.

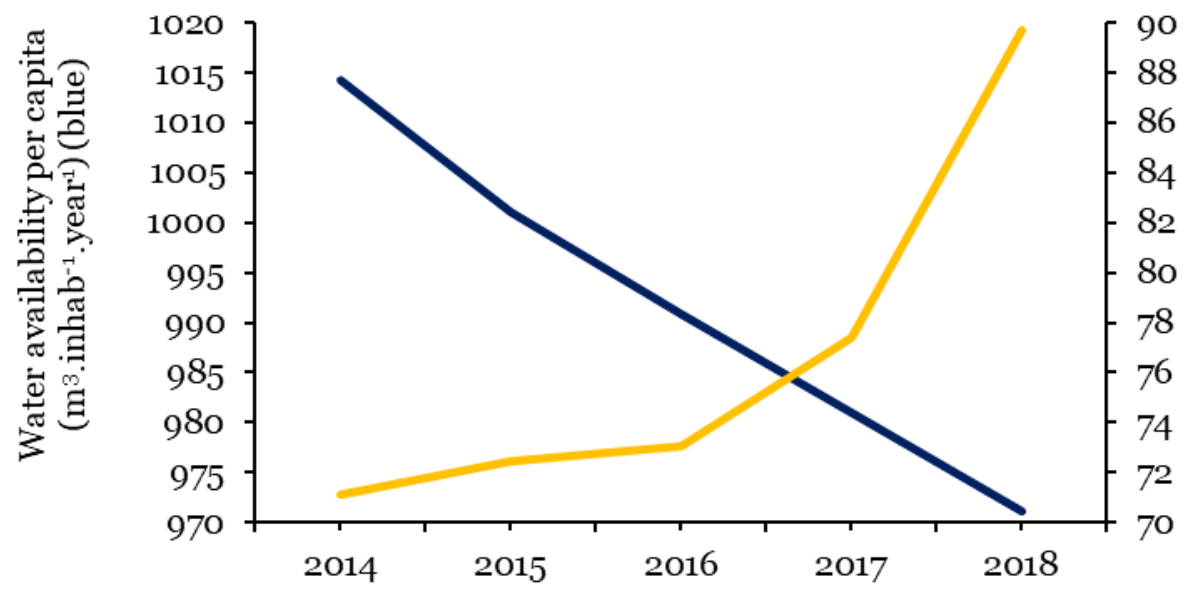

Source: Elaborated by the authors with PCJ Basin Agency data (2020).

Even though the region has a high number of surface springs of regional interest and with great flows volumes (AGÊENCIA DAS BACIAS PCJ, 2020), over a five-year period there has been a reduction of $4 \%$ in water availability. Since 2014 , the figures have been below what is considered to be the critical volume $\left(1,500 \mathrm{~m}^{3}\right.$. inhab-1.year $\left.{ }^{-1}\right)(\mathrm{SA} O$ PAULO, 2020) and population growth has a lot to do with that. As a ramification of the 2014 water supply crisis, subterranean water capture has come to have greater participation in supply (4\% and 11\% of the total in the years 2014 and 2018, respectively). There have been outstanding efforts made by the Water and Electricity Department (Departamento de Águas e Energia Elétrica - DAEE) in regularizing deep well concessions. In their assessment of the water supply system of São José do Rio Preto in the state of São Paulo, Oliveira et al. (2019) identified a gradual decline in water availability and an unwise increase in the number of wells over the years in a system that is on the verge of collapse. Although the basins are far apart, there is a considerable similarity with the PCJ basins as both sets of basins are trending in a contrary direction to what could be expected for sustainable development, as Flint (2004) and Feil and Schreiber (2017) have underscored.

Guaranteeing water quality and quantities for future generations is one of the targets (6.3) of SDG 6 (Chart 1). One way of achieving it is to reduce the load of pollutant discharge into the water bodies through actions that go beyond the usual engineering solutions, such as recuperating areas of gallery forest. The objectives stipulated in the WRP 2020-2035 for the PCJ basins include improving wastewater collection and treatment systems. The unrestricted ceiling target for 2035 is $98 \%$ of all wastewater collected and $100 \%$ treated. Should that effectively be achieved, then it will have achieved target 6.3 of SDG 6 which is to reduce by half the proportion of untreated wastewater.

In the current scenario, according to the WRP synthesis report for the PCJ basins 
(AGÊNCIA DAS BACIAS PCJ, 2020), the critical areas in regard to water resource management refer to the aspects of: guaranteeing water supply; land use and soil conservation in rural areas and forest vegetation recuperation; and the regimentation of bodies of water. Under the last heading come themes such as universalizing wastewater collection and its secondary and tertiary treatment (nitrogen and phosphorus removal). It even establishes priorities among the actions among the municipalities of the UGRHI, with timeframes and investments designed to achieve the targets set for the years 2025, 2030 and 2035.

Table 1 displays the annual wastewater data for the PCJ Basins for the period 2014 to 2018 .

Table 1 - Annual wastewater scenarios for the PCJ Basins for the period 2014 to 2018.

\begin{tabular}{cccc} 
Year & Collected Wastewater (\%) & Treated Wastewater (\%) & Collected and Treated Wastewater (\%) \\
2014 & 92.3 & 72.7 & 67.1 \\
2015 & 93.0 & 72.6 & 67.5 \\
2016 & 91.0 & 73.1 & 66.5 \\
2017 & 92.2 & 76.1 & 70.2 \\
2018 & 93.3 & 76.8 & 71.7 \\
\hline
\end{tabular}

Source: Elaborated by the authors with PCJ Basin Board data (2020).

As can be seen, the expansion of the wastewater network has failed to accompany the region's populational and territorial growth. Nevertheless, there have been improvements in the treatment aspect. Intensive efforts are needed if the universalization within ten years (2030) that the SDG 6 foresees is to be achieved. As previously mentioned, in general the classification of the wastewater collection and treatment was considered good in $60 \%$ e $38 \%$ of the PCJ basins municipalities respectively (AGÊNCIA DAS BACIAS PCJ, 2020). There is thus a need to assess the treated wastewater as a percentage of the total generated amount. Analyzing the treated percentage of the collected amount conceals the portion that is not collected. As an example, in the city and municipality of Jarinu, $100 \%$ of the wastewater collected is treated. However not all the generated wastewater is collected and in fact the percentage of the total amount generated that is treated is a mere $19 \%$.

The actions of the PCJ Consortium are related to the SDGs, especially those that address the question of the availability and sustainable management of water and sanitation (SDG 6) and the sustainable use of the terrestrial ecosystems (SDG 14) albeit this study does not address the latter. In general terms the target 6.2 foresees adequate, equitable and universal access to basic sanitation and an end to open defecation. The six high-priority actions of the set of targets (2020-35) elaborated for the ECA Plan in terms of wastewater in urban areas are concentrated in the elaboration of studies and projects and the implantation of wastewater treatment stations or improvements in exist- 
ing secondary treatment stations, which call for extended timeframes and large investments for them to be carried out. The measures are designed to achieve the unrestricted ceiling scenario (2035). Projects to improve wastewater collection and transportation and progress in tertiary treatment studies are also among the set of targets but with less priority due to the high investments involved. On that point, among the list of targets established for the PCJ basins, universal access to urban sanitation seems to be one that is being effectively addressed.

In the case of rural areas, the CRF Plan only established a single target which was to replace rudimentary wastewater treatment systems with other more efficient ones. Currently $33 \%$ of the wastewater systems discharge is into rudimentary septic tanks, contributing towards contaminating the soil and the water tables. The problem is all the greater because of the increased demand for underground water to meet the hydric scarcity of the State of São Paulo. The target for the year 2035 is attributed 'high' priority (not 'very high' priority) and the investments are more modest than those in projects for the installation and adaptation of wastewater systems in urban areas.

\subsection{Water Security Diagnosis and Forecasts for the PCJ Basins}

The PCJ Basins Plan (COMITÊ DAS BACIAS PCJ, 2020) estimates there will be a $22 \%$ increase in the population and a 24\% increase in water demand by the year 2035 . That population increase may well lead to the degradation of the water bodies stemming from the increased generation and discharge of wastewater. Thus it is essential to maximize the water supply and delineate wastewater management plans with a view to avoiding great risk to water security.

Horizons in regard to water demand, return and losses have been estimated for the years 2025, 2030 and 2035. For the 2035 scenario, various levels of intervention were analyzed, ranging from the actual absence of any measures at all to the application of water reuse. The respective studies show that reservoirs improve the hydric balance but they are not sufficient to bring the criticality of the rivers down to a low level (COMITÊ DAS BACIAS PCJ, 2018). Furthermore, such works are incapable of solving the problem of high criticality in some regions (e.g., parts of the Atibaia, Capivari and Jaguari rivers). Alternative measures such as water reuse and controlling losses are more efficient in minimizing demand.

The actions show that merely constructing works of a quantitative nature is not sufficient to align with the principles of Gibson such as sufficient resources for the local population $\left(2^{\text {nd }}\right.$ principle), intragenerational equity ( $3^{\text {rd }}$ principle), and intergenerational equity ( $4^{\text {th }}$ principle). Nevertheless, the surveys served as the basis for identifying problems in the proposed actions with a view to adapting the situation in the long term in accordance with Gibson's $8^{\text {th }}$ principle. Thus there is a patent need to improve the quality of the waters in the region.

The PCJ Basins Agency made simulations to gain an understanding of the impact on the quality of the rivers stemming from population growth. The Agency evaluated 
scenarios for the years 2025, 2030 and 2035 considering wastewater collection and treatment indices and the efficiency of pollutant removal on the part of the Wastewater Treatment Plants (WWTPs) (Chart 2). The simulation adopting a flow $\mathrm{Q}_{7,10}$ for the consolidated 2020 scenario revealed that $24 \%, 34 \%, 52 \%, 68 \%, 87 \%$ and $100 \%$ of stretches of rivers of PCJ basins meet the requirements in regard to phosphorus, thermotolerant coliforms, Biological Oxygen Demand (BOD), Chemical Oxygen Demand, ammoniacal nitrogen, nitrite and nitrate, respectively. There is a significant increase in nitrogen and phosphorus removal in the future scenarios reflecting the high level of investments in tertiary treatment in the WWTPs. Actually that also reveals the flaws in the present day socioecological system (Gibson's $1^{\text {st }}$ principle). In the ceiling scenario without restrictions, for 2035, there is an improvement in total phosphorus, thermotolerant coliforms and BOD (regimentation of $76 \%, 96 \%$ and $74 \%$ of the stretches, respectively). In that respect, the universal collection of wastewaters could avoid the contamination of the population and improve public health and wellbeing.

Furthermore, the responses obtained from the simulations revealed how even with heavy investments to achieve the ceiling scenario for $2035,45 \%$ of the stretches of the basin would not conform to all the requirements elucidated. In addition, improvements in the included areas could generate extra costs but without bringing any expressive extra benefits. An assessment was made of the prioritized areas which revealed that there is an increase in efficiency of the Action Plan. In that situation, $80 \%, 89 \%, 85 \%$ and $95 \%$ of the river stretches would be within the parameters for $\mathrm{BOD}$, ammoniacal nitrogen, phosphorus and thermotolerant coliforms, respectively, and it would be possible to increase the percentages of stretches that conform to the desired parameters from $45 \%$ to $61 \%$. The results show that there is a democratic trend in terms of governance, thereby respecting Gibson's (2006b) $6^{\text {th }}$ principle insofar as public expenditure would be more responsible. Such actions are efficacious in increasing water security in the basins, enhancing the quality of the waters and increasing the water supply. 
Chart 2 - Description of the studied scenarios.

\begin{tabular}{|c|c|c|}
\hline Scenarios & Simplified description & $\begin{array}{l}\text { BOD, N, P efficiency } \\
\text { and Coliforms* }\end{array}$ \\
\hline Zero Scenario (2016) & $\begin{array}{l}\text { Scenario with } 2016 \text { population - WWTPs active } \\
\text { in STAGE } 1 \\
\text { (Calibration Scenario) }\end{array}$ & $\begin{array}{l}\text { BOD: Current } \\
\text { N: } 35 \% \\
\text { P: } 20 \% \\
\text { Colif: } 99 \%\end{array}$ \\
\hline $\begin{array}{l}\text { Consolidated } \\
\text { Scenario (2020) }\end{array}$ & $\begin{array}{l}\text { Base Scenario for comparison purposes } \\
\text { Population in } 2020 \\
\text { WWTPs in expansion/ construction }\end{array}$ & $\begin{array}{l}\text { BOD: Current } \\
\text { N: } 35 \% \\
\text { P: } 20 \% \\
\text { Colif.: } 99 \%\end{array}$ \\
\hline $\begin{array}{l}\text { Meta-Scenario } \\
\text { Discharge Patterns }\end{array}$ & $\begin{array}{l}\text { Assessment for } 80 \% \text { maximum efficiency in the } \\
\text { WWTPs } \\
\text { Population in } 2035\end{array}$ & $\begin{array}{l}\text { BOD: } 80 \% \\
\text { N: } 35 \% \\
\text { P: } 20 \% \\
\text { Colif.: } 99 \% \\
\end{array}$ \\
\hline $\begin{array}{l}\text { Meta-Scenario with } \\
\text { restriction (2035) }\end{array}$ & $\begin{array}{l}2010 \text { to } 2020 \text { Plan targets assessment (Cobrape, } \\
2010 \text { ) } \\
\text { Population in } 2035 \\
\text { BOD efficiency is restricted by the ceiling }(95 \%)\end{array}$ & $\begin{array}{l}\text { BOD max.: } 95 \% \\
\text { N: } 60 \% \\
\text { P: } 35 \% \\
\text { Colif.: } 99.9 \%\end{array}$ \\
\hline $\begin{array}{l}\text { Meta-Scenario without } \\
\text { restriction } \\
(2035)\end{array}$ & $\begin{array}{l}2010 \text { to } 2020 \text { Plan Assessment (Cobrape, } 2010) \\
\text { Population in } 2035 \\
\text { BOD efficiency: not restricted by the ceiling } \\
(95 \%)\end{array}$ & $\begin{array}{l}\text { BOD max.: }>95 \% \\
\text { N: } 60 \% \\
\text { P: } 35 \% \\
\text { Colif.: } 99.9 \%\end{array}$ \\
\hline Ceiling Scenario (2035) & $\begin{array}{l}\text { Ceilings assessment (TR premises) } \\
\text { Population in } 2035 \\
\text { Collection: } 98 \% \text {; Treat. } 100 \% \text {; eff. } 95 \% \\
\text { BOD efficiency: restricted by the ceiling (95\%). }\end{array}$ & $\begin{array}{l}\text { BOD max.: } 95 \% \\
\text { N: } 75 \% \\
\text { P: 75\% } \\
\text { Colif.: } 99.99 \%\end{array}$ \\
\hline $\begin{array}{l}\text { Ceiling Scenario } \\
\text { without restriction } \\
(2035)\end{array}$ & $\begin{array}{l}\text { Ceiling assessment (TR premises) } \\
\text { Population in } 2035 \\
\text { Collection: } 98 \% \text {; Treartment: } 100 \% \\
\text { BOD efficiency: not restricted by the ceiling } \\
(95 \%) \text {. }\end{array}$ & $\begin{array}{l}\text { BOD max.: }>95 \% \\
\text { N: } 95 \% \\
\text { P: } 99 \% \\
\text { Colif.: } 99.999 \%\end{array}$ \\
\hline
\end{tabular}

BOD: Biological Oxygen Demand; N: Nitrogen; P: Phosphorus; Colif.: Thermotolerant Coliforms

* Efficiencies established for new WWTPs or with no information. For WWTPs with efficiencies equal to or over those established by the Scenario, current efficiencies are maintained except for the Meta-Scenario.

Source: Elaborated by the authors with PCJ Basin Agency data (2020).

Even after optimizing costs for a better regimentation scenario, the strategic theme of ECA needs to receive almost 7 billion reals. Of that amount more than 3 billion, 
equivalent to $40 \%$ of the investments, are earmarked for the tertiary treatment theme. Of the remainder, half is designated for water resource management. There is greater capital directed at targets 6.2 and 6.3 of SDG 6, mainly focused on water security for the populations and the quality of the bodies of water. The plan provides for spending approximately 34 million reals on Environmental Education, and Research and Technology Integration and Diffusion for greater socioenvironmental civility in the region, again in consonance with Gibson's (2006b) $5^{\text {th }}$ principle. Furthermore, the plan reveals that there are actions contemplated for the collection, transportation and treatment of wastewater generated in a centralized manner in the WWTPs. However, the scenario simulations focusing on critical areas showed that there was a significant increase in the regimentation of stretches in the basins. In that sense, studies focusing on even smaller scales could be made to verify the effectiveness of localized wastewater treatment; a decentralized treatment system could reduce WWTP construction costs.

\section{Conclusions}

The wastewater collection and treatment indicators that the WRP for the PCJ Basins proposes are important means to measuring the evolution of sustainability in relation to SDG 6, especially targets 6.2 and 6.3. For an unrestricted ceiling target (2035) achievement of the set objectives is in progress. However, the question of wastewater treatment is being addressed only in the aspect of collected wastewater and not of the total amount generated, thereby jeopardizing the possibility of making a more assertive decision. The portion of generated wastewater that fails to be considered has significant polluting potential and when discharged into the basins' hydric bodies can lead to a reduction in the quality of their waters.

In regard to the ceiling target set for the 2035 reference scenario, it can be considered valid insofar as it contributes to the following of Gibson's principles: 2) resources sufficient for subsistence and access to opportunities; 3) Intragenerational equity: 4) Intergenerational equity; and 5) natural resource maintenance. The analyzed indicators contribute to showing the evolution of the impact on water availability sufficiency and favor actions with a greater probability of preserving or increasing opportunities for future generations to live sustainably. The reference scenario reproduces the concern to guarantee sufficient water for all and provide a wider base of water resources to guarantee that while, at the same time, minimizing harm from effluent discharge avoiding waste and cutting the general use of materials and energy per unit of benefit.

\section{Acknowledgements}

The authors wish to thank the Coordinating Body for the Improvement of Higher Education Personnel (Coordenação de Aperfeiçoamento de Pessoal de Nivel Superior - CAPES) for its support. - Financing Code 001. 


\section{References}

AGÊNCIA DAS BACIAS PCJ. Disponibilidade Hídrica: águas superficiais, jan. 2020. Available at: http://www.agenciapcj.org.br/novo/informacoes-das-bacias/disponibilidade-hidrica. Accessed on: September 04, 2020.

AGENDA 2030. Os 17 Objetivos de Desenvolvimento Sustentável. Available at: http://www. agenda2030.org.br/ods/6/. Accessed on: September 04, 2020.

BOND, A. et al. Sustainability assessment: the state of the art. Impact Assessment and Project Appraisal, v. 30; n. 1, p. 53-62, 2012.

BRASIL. Ministério do Desenvolvimento Regional. ANA: Agência Nacional de Águas e Saneamento Básico. ODS 6 no Brasil: visão da ANA sobre os indicadores. Brasília: ANA, 2019a. 94 p. Available at: https:/www.ana.gov.br/acesso-a-informacao/institucional/publicacoes/ods6/ ods6.pdf. Accessedon: September 23, 2020.

BRASIL. Ministério do Desenvolvimento Regional. ANA: Agência Nacional de Águas e Saneamento Básico. Conjuntura dos recursos hídricos no Brasil 2019: informe anual / Agência Nacional de Águas. Brasília: ANA, 2019b. Available at: http://conjuntura.ana.gov.br/static/media/conjuntura-completo.bb39ac07.pdf. Accessed on: September 23, 2020.

BRASIL. Ministério do Planejamento, Desenvolvimento e Gestão. IBGE: Instituto Brasileiro de Geografia e Estatística. Censo 2010. Brasília: Diário Oficial da União, 04 nov. 2010. Available at: https://censo2010.ibge.gov.br/. Accessed on: September 04, 2020.

COMITÊ DAS BACIAS PCJ. Primeira Revisão do Plano das Bacias Hidrográficas dos Rios Piracicaba, Capivari e Jundiaí 2010 a 2020-Relatório Final-Tomo IV-Plano de Ações. 5. rev, Consórcio Profill-Rhama PCJ, abr. 2018.

COMITÊ DAS BACIAS PCJ. Relatório de situação dos recursos hídricos: versão simplificada - ano base 2019. Fundação Agência das Bacias PCJ. Piracicaba: [s.n.], 2019. Available at: http://www.agencia.baciaspcj.org.br/docs/relatorios/relatorio-situacao-2019/relatorio-situacao-2019.pdf. Accessed on: September 23, 2020.

COMITÊ DAS BACIAS PCJ. Relatório Síntese: Plano de Recursos Hídricos das Bacias Hidrográficas dos rios Piracicaba, Capivari e Jundiaí, 2020 a 2035. Porto Alegre: Consórcio Profill-Rhama PCJ, 2020. Available at: https://agua.org.br/biblioteca/relatorio-sintese-pbh-pcj/. Accessed on: September 28, 2020.

DOVERS, S.R.; HANDMER, J.W. Uncertainty, sustainability and change. Global Environmental Change, v.2, n.4, p.262-276, 1992.

EMPRESA PAULISTA DE PLANEJAMENTO METROPOLITANO (EMPLASA). Projeto Mapeia Paulo: Projeto de Atualização Cartográfica do Estado de São Paulo. Base de dados: 2010/2011. São 4582 Paulo, 2015. 4583

ESTEVES, A. M. et al. Social impact assessment: the state of the art. Impact Assessment and 
Project Appraisal, v. 30, n. 1, 2012.

FEIL, A. A.; SCHREIBER, D. Sustentabilidade e desenvolvimento sustentável: desvendando as sobreposições e alcances de seus significados. Caderno EBAPE, v. 14, n. 3, 2017.

FLINT, R. Warren the sustainable development of water resources. Water Resources Update, n. 127, p. 41-51, 2004.

FLINT, R. W. Practice of Sustainable Community Development. New York: Springer, 2013.

GALLOPÍN, G.C. Sostenibilidad y desarrollo Sostenible: un enfoque sistémico. Medio Ambiente y Desarrollo, 2003.

GIBSON, R. B. et al. Sustainability Assessment: Criteria, Processes and Applications. London: Earthscan, 254 p, 2005.

GIBSON, R. B. Beyond the pillars: Sustainability assessment as a framework for effective integration of social, economic and ecological considerations in significant decision-making. Journal of Environmental Assessment Policy and Management v. 8, n. 3, p. 259-280, 2006a.

GIBSON, R. B. Sustainability-based assessment criteria and associated frameworks for evaluations and decisions: theory, practice and implications for the Mackenzie Gas Project Review. Review Literature and Arts of The Americas n. January, p. 56, 2006 b.

GIBSON, R. B. Sustainability assessment: Basic components of a practical approach. Impact Assessment and Project Appraisal v. 24, n. 3, p. 170-182, 2006c.

GIBSON, R. B. Why sustainability assessment? In: A. Bond, A. Morrison-Saunders e R. Howitt, eds. Sustainability assessment: pluralism, practice and progress. Capítulo 1, 1a ed. Londres, 2012.

GIOVANNONI, E.; FABIETTI, G. What is sustainability? A review of the concept and its applications. Integrated Reporting, p. 21-40, 2014.

HACKING, T.; GUTHRIE, P. A framework for clarifying the meaning of Triple Bottom-Line, Integrated, and Sustainability Assessment. Environmental Impact Assessment Review, v. 28, n. 2-3, p. 73-89, 2008.

Instituto Brasileiro de Geografia e Estatística (IBGE). Censo Brasileiro de 2010. Rio de Janeiro: IBGE, 2012.

MATTAR, F. N. Pesquisa de marketing. 2 ed. São Paulo: Atlas, 2000.

OLIVEIRA, J. N. et al. O conflito entre a expansão urbana e o uso da água subterrânea. Journal of Hyperspectral Remote Sensing, v. 9, p. 373-386, 2019.

PNUD-BR. Programa das Nações Unidas para o Desenvolvimento - Brasil. Objetivos de Desenvolvimento Sustentável. Available at: https:/www.br.undp.org/content/brazil/pt/home/sustaina- 
ble-development-goals.html. Accessed on: October 19, 2020.

ROMA, J. C. Os Objetivos de Desenvolvimento Sustentável do Milênio e sua transição para os Objetivos de Desenvolvimento Sustentável. Indicadores de Sustentabilidade, 2019.

SARTORI, S.; LATRÔNICO, F; CAMPOS, L.M.S. Sustentabilidade e Desenvolvimento Sustentável: uma taxonomia no campo da literatura. Ambiente $\&$ Sociedade, v. 17, n. 1, p. 1-22, 2014.

SÃO PAULO (Estado). CRHi: Coordenadoria de Recursos Hídricos do Estado de São Paulo. Relatório de situação dos recursos hídricos da bacia hidrográfica: roteiro para elaboração e fichas técnicas dos parâmetros. Outubro de 2020. Available at: http://www.sigrh.sp.gov.br/ relatoriosituacaodosrecursoshidricos. Accessed on: September 04, 2020.

SILVA. E. R. A. da (Coord.). Agenda 2030: ODS - Metas Nacionais dos Objetivos de Desenvolvimento Sustentável. Brasília: IPEA, 2018. Available at: http://repositorio.ipea. gov.br/handle/11058/8855\%0Ahttps://www.ipea.gov.br/portal/index.php?option= com content\&id=33895. Accessed on: October 19, 2020.

SINGH, R. K. et al. An overview of sustainability assessment methodologies. Ecological Indicators, v. 15, n. 1, 2012.

UNITED NATIONS WATER. Water security \& the global water agenda. UN Water Analytical Brief. Hamilton, Canada: UN University, 2013.

WCED. Our common future. Oxford: Oxford University Press, 1987

WU, J.; WU, T. Sustainability indicators and indices: An overview. Handbook of Sustainability Management, p. 65-86, 2012. 
João Miguel Merces Bega

$\varangle$ joaobega@usp.br

ORCiD: https://orcid.org/0000-0003-4386-5488

André do Vale Borges

$\varangle$ andreborges@usp.br

ORCiD: https://orcid.org/0000-0002-8154-5736

César Ambrogi Ferreira do Lago

cesarlago@usp.br

ORCiD: https://orcid.org/0000-0002-0387-0226

Jakeline Pertile Mendes

$\varangle$ jakeline.pm@puccampinas.edu.br

ORCiD: https://orcid.org/0000-0002-0659-8424

Paulo de Tarso de Azevedo

$\checkmark$ paulo_azevedo@usp.br

ORCiD: https://orcid.org/0000-0001-6972-219X

Welington José Rocha dos Santos

santos.welington@usp.br

ORCiD: https://orcid.org/0000-0001-8641-1430

Duarcides Ferreira Mariosa

$\varangle$ duarcidesmariosa@puc-campinas.edu.br

ORCiD: https://orcid.org/0000-0001-6552-9288
Submitted on: 09/03/2021

Accepted on: 13/07/2021

2021;24e:0247 


\title{
Avaliação da Sustentabilidade dos Indicadores de Saneamento do Plano das Bacias PCJ 2020-2035
}

\author{
João Miguel Merces Bega \\ André do Vale Borges \\ César Ambrogi Ferreira do Lago \\ Jakeline Pertile Mendes \\ Paulo de Tarso de Azevedo \\ Welington José Rocha dos Santos \\ Duarcides Ferreira Mariosa
}

São Paulo. Vol. 24, 2021

Dossiê Especial:

Sustentare e Workshop Internacional sobre Indicadores de Sustentabilidade (WIPIS)
Resumo: Dada a limitação dos recursos naturais frente ao aumento crescente de sua demanda, torna-se imperativo conhecer como se comportam as diversas variáveis que compõem o processo de sustentabilidade hídrica. Apoiado na técnica de estudo de caso e na pesquisa de natureza exploratória, o presente trabalho objetivou analisar os índices de esgoto coletado e de esgoto tratado presentes no Plano de Recursos Hídricos das Bacias PCJ para o período 2020-35. Buscou-se validar os indicadores com os princípios de sustentabilidade de Gibson, relacionando-os, igualmente, às metas 6.2 e 6.3 do Objetivo de Desenvolvimento Sustentável (ODS) 6. Concluiu-se que os indicadores são importantes para mensurar o processo rumo ao alcance do ODS 6, mas apresentam falhas, mascarando informações importantes para uma tomada de decisão mais assertiva. Em relação à meta de atendimento ao cenário de referência de 2035, foi observada a sua validade por quatro princípios de Gibson.

Palavras-chave: Indicadores de sustentabilidade; ODS 6; princípios de Gibson; bacias sustentáveis.

Como citar: BEGA, J. M. M.; BORGES, A. V.; LAGO, C. A. F.; MENDES, J. P.; AZEVEDO, P. T.; SANTOS, W. J. R.; MARIOSA, D. F. Avaliação da Sustentabilidade dos Indicadores de Saneamento do Plano das Bacias PCJ 2020-2035. Ambiente \& Sociedade. São Paulo, v. 24, p. 1-220, 2021. 


\title{
Evaluación de sostenibilidad de Indicadores de Saneamiento en el Plan de las Cuencas del PCJ 2020-2035
}

\author{
João Miguel Merces Bega \\ André do Vale Borges \\ César Ambrogi Ferreira do Lago \\ Jakeline Pertile Mendes \\ Paulo de Tarso de Azevedo \\ Welington José Rocha dos Santos
}

São Paulo. Vol. 24, 2021

Dossier Especial: Sustentare y Workshop Internacional sobre Indicadores de Sustentabilidad (WIPIS)
Resumen: Dada la limitación de los recursos naturales ante la creciente demanda, es imperativo conocer cómo se comportan las distintas variables que componen el proceso de sostenibilidad del agua. Apoyado en la técnica de estudio de caso e investigación exploratoria, el presente estudio tuvo como objetivo analizar los indicadores de aguas servidas recolectadas y tratadas presentes en el Plan de Recursos Hídricos de las Cuencas del PCJ para el período 2020-35. Buscamos validar los indicadores contra los principios de sostenibilidad de Gibson, relacionándolos con las metas 6.2 y 6.3 del Objetivo de Desarrollo Sostenible (ODS) 6. Se concluyó que los indicadores son importantes para medir el proceso hacia el logro del ODS 6, sin embargo, poseen fallas que ocultan información importante para la toma de decisiones más asertiva. En relación al objetivo de cumplir con el escenario de referencia de 2035, su validez fue observada por cuatro principios de Gibson.

Palabras-clave: Indicadores de sostenibilidad; ODS 6; principios de Gibson; cuencas sostenibles.

Como citar: BEGA, J. M. M.; BORGES, A. V.; LAGO, C. A. F.; MENDES, J. P.; AZEVEDO, P. T.; SANTOS, W. J. R.; MARIOSA, D. F. Evaluación de sostenibilidad de Indicadores de Saneamiento en el Plan de las Cuencas del PCJ 2020-2035. Ambiente \& Sociedade. São Paulo, v. 24, p. 1-20, 2021.

DOI: http://dx.doi.org/10.1590/1809-4422asoc20190031r3vu2021L3AO 